\title{
Structural and Activity Changes in Renal Betaine Aldehyde Dehydrogenase Caused by Oxidants
}

\author{
Jesús A. Rosas-Rodríguez ${ }^{1}$, Hilda F. Flores-Mendoza², \\ Ciria G. Figueroa-Soto' ${ }^{2}$ Edgar F. Morán-Palacio ${ }^{1}$ \\ and Elisa M. Valenzuela-Soto ${ }^{2 *}$ \\ ${ }^{1}$ Departamento de Ciencias Químico Biológicas y Agropecuarias, \\ Universidad de Sonora Unidad Regional Sur, Navojoa, Sonora, \\ ${ }^{2}$ Centro de Investigación en Alimentación y Desarrollo A.C., Hermosillo, Sonora, \\ México
}

\section{Introduction}

Oxidative stress has been implicated in a variety of diseases such as glomerulonephritis and tubulointerstitial nephritis, renal insufficiency, proteinuria, Alzheimer's and Parkinson's disease, diabetes and hypertension, as well as contributing to the pathogenesis of ischemia reperfusion injury in the kidney (Banday \& Lokhandwala, 2011; Martin \& GoeddekeMerickel, 2005; Touyz, 2004; Vaziri, 2004). One of the most important functions of kidney is the regulation of liquid volume. Broad shifts in osmolality, high urea concentrations and low oxygen tension are required by the urine concentrating mechanism to produce concentrated urine (Kwon et al., 2009; Burg \& Ferraris, 2008; Neuhofer \& Beck, 2006). There is evidence indicating that the osmotic stress and low oxygen tension produced in medullary cells generates an increase in the concentration of reactive oxygen species (ROS), which triggers damage to kidney cells.

The source of ROS in kidney is (1) the hyperosmolality of the environment where the medulla cells are found, (2) NADH oxidase activity and (3) the mitochondrial respiratory chain (Banday \& Lokhandwala, 2011; Harper et al., 2004; Mori \& Crowley, 2003; Zou et al., 2001). The most abundant ROS in renal cells are the superoxide radical $\left(\mathrm{O}_{2}-\right)$ and hydrogen peroxide $\left(\mathrm{H}_{2} \mathrm{O}_{2}\right)$. Hydrogen peroxide is produced during the incomplete reduction of oxygen to $\mathrm{H}_{2} \mathrm{O}$, and it is biologically important because it is reduced to the highly reactive hydroxyl radical (Rhee et al., 2003). The hydroxyl radical has been implicated in endothelial dysfunction (Coyle et al. 2006). The amount of ROS produced is in balance with the quantity eliminated by the antioxidants. However, when this balance is upset the possibility of cellular damage by ROS increases (Haliwell, 2007; Lushchak 2011).

Metal ions such as iron, cadmium and copper have been found to play a role in several human diseases owing to their capacity to generate oxidative stress (Bonda et al., 2011;

* Corresponding Author 
Butterworth, 2010; Jomova \& Valko, 2011; Jomova et al., 2010). Copper generates ROS (hydroxyl $\bullet \mathrm{OH}$ and superoxide anion radical $\mathrm{O}_{2} \bullet$ ) by two mechanisms: Fenton and/or HaberWeiss chemistry (Jomova \& Valko, 2011; Prousek, 2007) and by decreasing glutathione levels (Speisky et al., 2009). Glutathione has several functions including acting as a powerful cell antioxidant and as a copper chelating agent; therefore decreased glutathione levels can enhance oxidative stress (Mattie \& Freedman, 2004; Steinebach \& Wolterbeek, 1994).

Copper ions display a high affinity to thiol groups in proteins and can directly bind to them causing enzyme inactivation or altered protein conformation (Giles et al., 2003; Letelier et al., 2005; Prudent \& Girault, 2009; Zhang et al., 2010). For example, the enzyme glutathione S-transferase (GST) from rat liver, crab and shrimp is inhibited by copper (Elumalai et al., 2002; Letelier et al., 2006; Salazar-Medina et al., 2010), and proteins such as LDL and HDL are also oxidized by copper (Burkitt, 2001). The thiol group exhibits a variety of oxidation states which allow for nucleophilic attack, electron transfer, hydride transfer and oxygen atom transfer (Giles et al., 2003). The binding between copper and the thiol group can oxidize the sulphur, producing sulfenic and sulfinic acids or a disulfide bridge between vicinal cysteines (Giles et al., 2003).

Identifying the proteins that are susceptible to oxidative damage could lead to a better understanding of the complexity of the alterations caused by oxidative stress, and allow us to counteract the injury caused by ROS. A decrease in the activity of the enzymes involved in osmolyte synthesis and stress response are associated with renal injury, and as such could generate other diseases in the organism. Further study of the regulation and biochemical characteristics of those enzymes is necessary in order to identify and understand the effects of ROS in kidney and their relationship to the osmolyte system. One of those enzymes is betaine aldehyde dehydrogenase (BADH EC 1.2.1.8), which catalyzes the oxidation of betaine aldehyde to synthesize glycine betaine.

Glycine betaine (GB) is one of the major non-perturbing osmolytes that are actively accumulated by plant, bacteria and mammalian cells under hypertonic conditions, and this process is important in the regulation of cell volume (Chen \& Murata, 2011; Burg \& Ferraris, 2008, Burg et al., 2007). Glycine betaine has also been found to suppress increases in oxidative stress in old rats (Go et al. 2005), prevent isoprenaline-induced myocardial infarction due to its antioxidant properties (Ganesan et al. 2009), prevent taurolithocholate 3-sulfate-induced oxidative stress in rat hepatocytes (Graf et al. 2002), activate chaperonemediated disaggregation-suggesting that GB has a specific interaction of activation with ClpB and/or DnK (Umenishi et al., 2005), and to promote aquaporine PI (AQPI) expression under severe hypertonic conditions in kidney (Diamant et al., 2001). Glycine betaine has been described as an osmoprotectant against deleterious effect of urea (Burg et al. 1996).

Betaine aldehyde dehydrogenase (BADH, EC 1.2.1.8) belongs to the superfamily of aldehyde dehydrogenases (ALDH9) (Julián-Sanchez et al., 2007; Vasiliou et al., 1999) and has been found in many prokaryotic and eukaryotic organisms. The enzyme has been purified from and characterized for a number of these sources: plants (Arakawa et al., 1987; Figueroa-Soto \& Valenzuela-Soto, 2001; Livingstone et al., 2003; Oishi \& Ebina, 2005; Pan, 1988; Valenzuela-Soto \& Muñoz-Clares, 1994; Weretylnik \& Hanson, 1989), microorganisms (Boch et al., 1997; Falkenberg \& Strom, 1990; Mori et al., 1992; Mori et al., 1980; Nagasawa et al., 1976; VelascoGarcia et al., 1999) and animals (Chern \& Pietruszko, 1999; Guzman-Partida \& ValenzuelaSoto, 1998; Hjelmquist et al., 2003; Kurys et al., 1989; Rothschil \& Guzman-Barron, 1954). 
Studies of steady-state kinetics have shown that BADH from swine kidney and amaranth plants follows an iso bi-bi ordered mechanism (Figueroa-Soto \& Valenzuela-Soto, 2000; Valenzuela-Soto \& Muñoz-Clares, 1993), that of Pseudomonas aeruginosa follows a random steady-state, with a much preferred route in which the nucleotide first links to the enzyme (Velasco-Garcia et al., 1999), and a ping-pong mechanism for the enzymes from the fungus Cylindrocarpon didymum (Mori et al., 1980), and the bacterium Escherichia coli (Falkenberg \& Strom, 1990). In an iso bi-bi ordered mechanism, NAD ${ }^{+}$is the first substrate to combine with the enzyme and $\mathrm{NADH}$ is the last product released.

The enzyme betaine aldehyde dehydrogenase from swine kidney (skBADH) requires renal physiological ionic strength to maintain its tetrameric conformation; at low ionic strength the enzyme dissociates, forming dimers which are inactive and very stable (Valenzuela-Soto et al., 2003). Additionally, the enzyme requires the physiological ionic strength provided by a monovalent cation for maximum thermostability (Valenzuela-Soto et al., 2005).

SkBADH, like the majority of aldehyde dehydrogenases, has a catalytic cysteine (Cys 288) (González-Segura et al., 2002; Muñoz-Clares et al., 2003), and also has a vicinal cysteine (Cys 289). The chemical mechanism of BADH involves the following steps: 1) There is a nucleophilic attack by the thiolate group of the catalytic cysteine on the carbon of carbonyl group of the aldehyde, forming the thiohemiacetal intermediate; 2) The transfer of the hydride to the C-4 position of the nicotinamide portion of $\mathrm{NAD}(\mathrm{P})^{+}$, thus reducing the nucleotide; 3) A water molecule acting as a nucleophile breaks the thioester bond, thus forming the acid product of the reaction (Muñoz-Clares \& Valenzuela-Soto, 2008; MuñozClares et al., 2010).

In previous studies, we found that in swine kidney $\mathrm{BADH}$ the thiolate from catalytic cysteine can be oxidized by hydrogen peroxide, forming a disulfide bond between catalytic and vicinal cysteine (Rosas-Rodríguez \& Valenzuela-Soto, 2011). With the aim of better understanding how ROS affect the stability and activity of the enzymes involved in osmolyte synthesis, in this study we examined the impact of hydrogen peroxide and copper on the activity, structure and stability of renal BADH. Physiological conditions such as $\mathrm{pH}$ and ionic strength were analyzed and contrasted with the conditions that are optimal for enzyme activity.

\section{Materials and methods}

\subsection{Chemicals}

Betaine aldehyde, DTT, EDTA, glycine betaine, GSH, HEPES, 2-mercaptoethanol, NAD+ (sodium salt), $\mathrm{KCl}$ and $\mathrm{CuCl}_{2}$ were obtained from Sigma-Aldrich SA de $\mathrm{CV}$, México. All other chemicals and solvents used in this study were of analytical grade.

\subsection{Enzyme purification and activity assay}

BADH was purified from porcine kidney tissue and its activity was assayed at $30{ }^{\circ} \mathrm{C}$ as previously reported (Guzman-Partida \& Valenzuela-Soto, 1998) with a modification in the affinity chromatographic step, where an N-6-Hexyl-AMP-sepharose matrix was used. The pure enzyme was stored at $-20{ }^{\circ} \mathrm{C}$ in a $10 \mathrm{mM}$ potassium phosphate buffer, $\mathrm{pH} 6.8,1 \mathrm{mM}$ EDTA, $14 \mathrm{mM}$ 2-mercaptoethanol, $0.2 \mathrm{M} \mathrm{KCl}$ and $10 \%$ glycerol. The standard assay system 
contained 0.1 M Hepes-KOH, pH 8.0, $0.5 \mathrm{mM}$ betaine aldehyde (BA) and $1.0 \mathrm{mM} \mathrm{NAD}^{+}$in a final volume of $0.4 \mathrm{~mL}$. SkBADH activity was assayed spectrophotometrically measuring $\mathrm{NAD}^{+}$reduction by the increase in extinction at $340 \mathrm{~nm}$ using an Ultrospec 4000 (Pharmacia) spectrophotometer.

Prior to treatments skBADH $(0.15 \mathrm{mg} / \mathrm{mL})$ was dialyzed overnight at $4{ }^{\circ} \mathrm{C}$ against $10 \mathrm{mM}$ Hepes-KOH buffer, pH 7.0, 1 mM EDTA, 10 mM 2-mercaptoethanol (buffer A, low ionic strength), and against buffer A plus $150 \mathrm{mM} \mathrm{KCl}$ (buffer B, physiological ionic strength).

\subsection{Effect of hydrogen peroxide in enzyme activity}

SkBADH activity in the presence of hydrogen peroxide was evaluated at distinct $\mathrm{pH}$ values and ionic strengths. The enzyme was assayed in the presence of $0.1 \mathrm{mM}$ of hydrogen peroxide in $10 \mathrm{mM}$ Hepes buffer, $\mathrm{pH}$ 6.8, 7.0, 7.2, 7.4 and 8.0 and enzyme activity was measured. The effect of ionic strength was evaluated by incubating the enzyme at each $\mathrm{pH}$ tested with $0.15 \mathrm{M} \mathrm{KCl}$ for 60 minutes prior to the enzyme activity assay.

\subsection{Kinetics of inactivation by copper}

The enzyme was dialyzed with $10 \mathrm{mM}$ Hepes buffer, $\mathrm{pH} 7$ or $\mathrm{pH} 8.0,10 \%$ glycerol (v/v), and $1 \mathrm{mM}$ 2-mercaptoethanol. The enzyme was incubated for $120 \mathrm{~min}$ with $10 \mu \mathrm{M} \mathrm{CuCl}_{2}$, in the presence or absence of $0.15 \mathrm{M} \mathrm{KCl}$, an aliquot was taken at different times and residual enzyme activity was measured by the standard assay. Rate constants for inactivation were calculated by fitting the data to a single exponential decay equation (Eq. 1) using OriginPro 8.0 (OriginLab, Northampton, MA, USA).

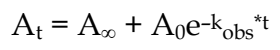

Where $A_{t}, A_{0}$ and $A_{\infty}$ are enzyme activity at time $t$, zero, and infinite, respectively, expressed as a percentage of the initial activity; $k_{\mathrm{obs}}$ is the observed pseudo-first order constant in monophasic inactivation.

\subsection{Enzyme reactivation kinetics}

The reactivation of inactivated enzyme was carried out with $5 \mathrm{mM}$ dithiothreitol (DTT), 10 $\mathrm{mM}$ glutathione (GSH) or $10 \mathrm{mM}$ 2-mercaptoethanol. An aliquot was taken at different times and enzyme activity was measured using the standard assay. Activity data were fitted to a double exponential growth equation (Eq. 2) using OriginPro 8.0.

$$
A_{t}=A_{1}\left(1-e^{-k_{\mathrm{obs}}} \cdot \mathrm{t}\right)+A_{2}\left(1-e^{-k_{\mathrm{obs}}} 2 \cdot \mathrm{t}\right)
$$

Where $A_{t}, A_{0}$ and $A_{\infty}$ are enzyme activity at time $\mathrm{t}$, zero, and infinite, respectively, expressed as a percentage of the initial activity; $k_{\mathrm{obs}}$ is the observed pseudo-first order constant in monophasic inactivation.

\subsection{Enzyme fluorescence assay}

Intrinsic tryptophan fluorescence was used to estimate skBADH fluorescence quenching by enzyme substrates (BA and $\left.\mathrm{NAD}^{+}\right)$, products (GB and $\left.\mathrm{NADH}\right)$ and inhibitors $\left(\mathrm{H}_{2} \mathrm{O}_{2}\right.$ and copper) at the concentrations given in each figure legend. Another set of experiments was 
carried out in which the enzyme was incubated for $120 \mathrm{~min}$ in the presence of $100 \mu \mathrm{M} \mathrm{H}_{2} \mathrm{O}_{2}$ or $10 \mu \mathrm{M} \mathrm{CuCl}_{2}$. Fluorescence spectra were recorded at an excitation wavelength of $296 \mathrm{~nm}$ and emission wavelength of 300-400 nm (5 nm bandwidth) using a QM-2003 fluorometer (Photon Technology International) with a 75-W xenon lamp as the light source. The spectra were corrected by subtracting the spectrum obtained for the solvent under identical conditions. Three readings of emission data were accumulated. The assay was done using 2 $\mu \mathrm{M}$ of enzyme monomer in $100 \mathrm{mM}$ Hepes-KOH buffer at $\mathrm{pH} 7.0$ and then at $\mathrm{pH} 8.0$. Fluorescence spectral centers of mass (intensity-weighted average emission wavelengths, $\left.\lambda_{\text {av}}\right)$ were calculated according to the following equation:

$$
\lambda_{\mathrm{av}}=\Sigma \lambda I(\lambda) / \Sigma I(\lambda)
$$

where $\lambda$ is the emission wavelength and $I(\lambda)$ represents the fluorescence intensity at wavelength $\lambda$.

\subsection{Enzyme structural models}

The structural model of the skBADH tetramer was constructed using MOE v2009.10 software (Chemical Computing Group). The homology model was built using the cDNAdeduced swine kidney BADH amino acid sequence. The crystallographic structures from cod liver (1A4S, DOI:10.2210/pdb1a4s/pdb) and Escherichia coli BADH (1WNB, DOI:10.2210/pdb1wnb/pdb) were used as templates to generate the final homology model.

The hydrogen peroxide and copper interaction models with the skBADH active site were built using the PyMOL Molecular Graphics System, Version 1.3, Schrödinger, LLC. The model was designed based on previously described experimental evidence of the alteration of skBADH active site (Rosas-Rodríguez \& Valenzuela-Soto, 2011).

\section{Results}

\subsection{Effect of $\mathrm{pH}$ and hydrogen peroxide on enzyme activity}

To test the influence of $\mathrm{pH}$ on skBADH oxidation provoked by hydrogen peroxide, enzyme activity was assayed from $\mathrm{pH} 6.8$ to 8.0. Enzyme activity was higher at $\mathrm{pH} 8.0$ in the absence or presence of hydrogen peroxide (Fig. 1). SkBADH activity decreased $50 \%$ in the presence of $100 \mu \mathrm{M} \mathrm{H}_{2} \mathrm{O}_{2}$ at all $\mathrm{pH}$ values tested relative to the enzyme assays done with no hydrogen peroxide (Fig. 1A). Chemical modification studies carried out with BADH from Pseudomonas aeruginosa indicated that the catalytic cysteine residue exists as thiolate at $\mathrm{pH}$ values of 5.5 to 9.0 (González-Segura et al., 2002). Therefore, $\mathrm{H}_{2} \mathrm{O}_{2}$ is able to oxidize the catalytic cysteine in the skBADH at the $\mathrm{pH}$ values assayed in this work.

Physiological ionic strength obtained using $0.15 \mathrm{M} \mathrm{KCl}$ was tested to analyze its influence on skBADH oxidation by $100 \mu \mathrm{M} \mathrm{H}_{2} \mathrm{O}_{2}$. Enzyme activity decreased $50 \%$ when hydrogen peroxide was included in the activity assay medium (Fig. 1B). Physiologic ionic strength was not able to maintain enzyme activity in the presence of hydrogen peroxide at any of the $\mathrm{pH}$ values tested (Fig. 1B).

Previous studies indicated that enzyme exposure to $\mathrm{Na}^{+}$or $\mathrm{K}^{+}$ions maintains more than $50 \%$ of skBADH activity and that physiological ionic strength is necessary to maintain the tetrameric structure of skBADH (Guzman-Partida \& Valenzuela-Soto, 1998; Valenzuela- 
Soto et al., 2003). SkBADH is inhibited in the presence of $100 \mu \mathrm{M} \mathrm{H}_{2} \mathrm{O}_{2}$, a concentration that may be found in medulla cells during concentrated urine formation, and which requires high osmolarity and low oxygen tension (Burg \& Ferraris, 2008; Neuhofer \& Beck, 2006). In addition, these peroxide concentrations may be found in the medulla cells of hypertensive (Touyz \& Briones, 2011; Thengchaisri \& Kuo, 2003) and diabetic patients (Coughlan et al., 2009; Forbes et al., 2008), i.e. pathologies related to high ROS concentrations.
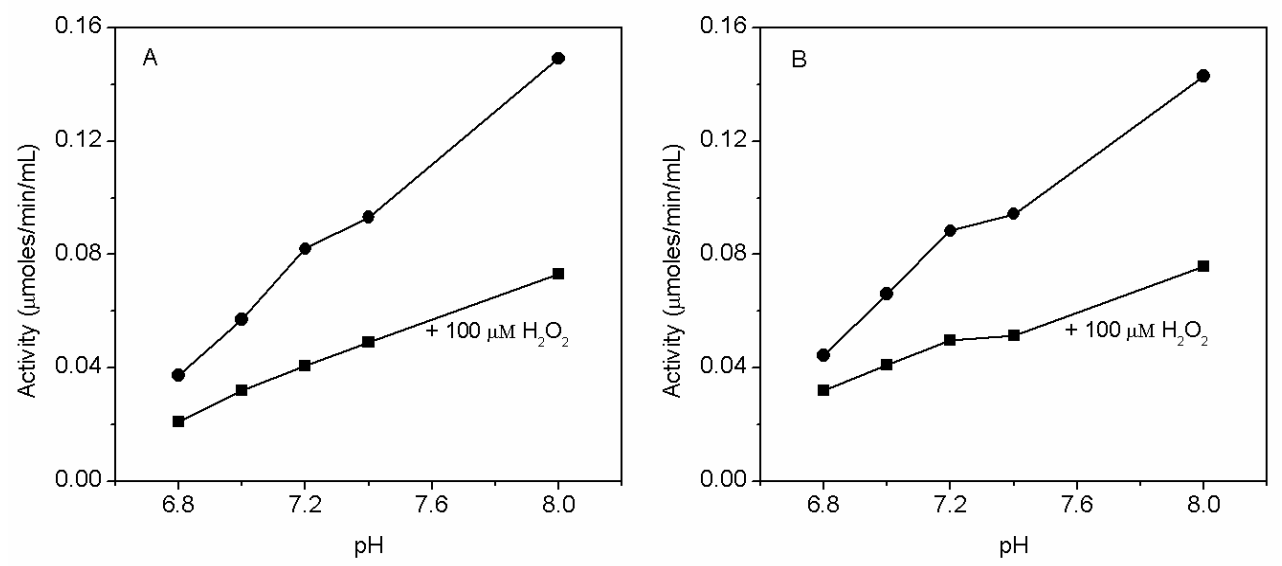

Fig. 1. Effect of $\mathrm{pH}$ and ionic strength on skBADH inactivation caused by hydrogen peroxide. Enzyme activity measured at: (A) low ionic strength; (B) physiological ionic strength $(0.15 \mathrm{M} \mathrm{KCl})$.

\subsection{The effect of hydrogen peroxide on enzyme fluorescence}

A methodical evaluation of the effect of hydrogen peroxide on enzyme tertiary structure was performed by incubating the enzyme in the presence of $0-0.5 \mathrm{mM} \mathrm{H}_{2} \mathrm{O}_{2}$. SkBADH maximum emission was detected at $333 \mathrm{~nm}$ (Fig. 2). Enzyme fluorescence was quenched by all hydrogen peroxide concentrations tested (Fig. 2), however fluorescence spectral centers of mass did not change and no blue or red shift was found.

A hydrogen peroxide concentration of $100 \mu \mathrm{M}$ was chosen to analyze the effect of incubation time on enzyme quenching, because this concentration can be found in kidney. When the enzyme was incubated for $120 \mathrm{~min}$ in the presence of $100 \mu \mathrm{M} \mathrm{H}_{2} \mathrm{O}_{2}$, the fluorescence of skBADH was quenched in a time dependent manner (Fig. 3). The presence of hydrogen peroxide decreased the skBADH maximum emission by more than $50 \%$ at $120 \mathrm{~min}$ of incubation. Changes in enzyme emission fit a single decay equation with an R-square of 0.9893 (Fig. 3 Inset). It is noteworthy that skBADH fluorescence quenching was only detected in the presence of peroxide and the shape of the fluorescence spectra did not change. The fluorescence spectral centers of mass did not change either. 


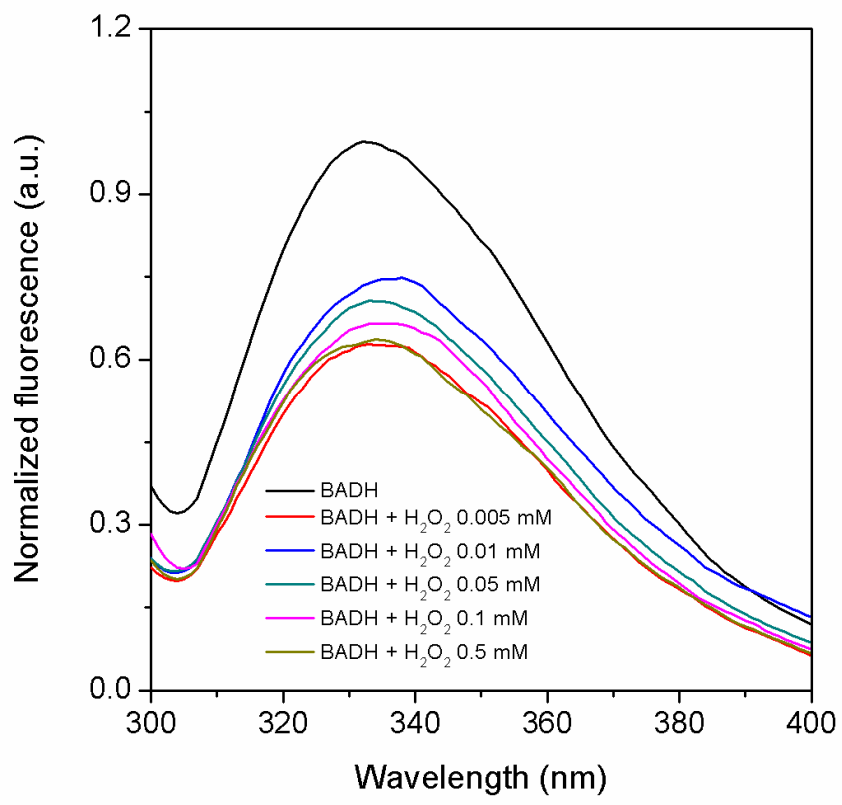

Fig. 2. Fluorescence spectra for skBADH in the presence of hydrogen peroxide.

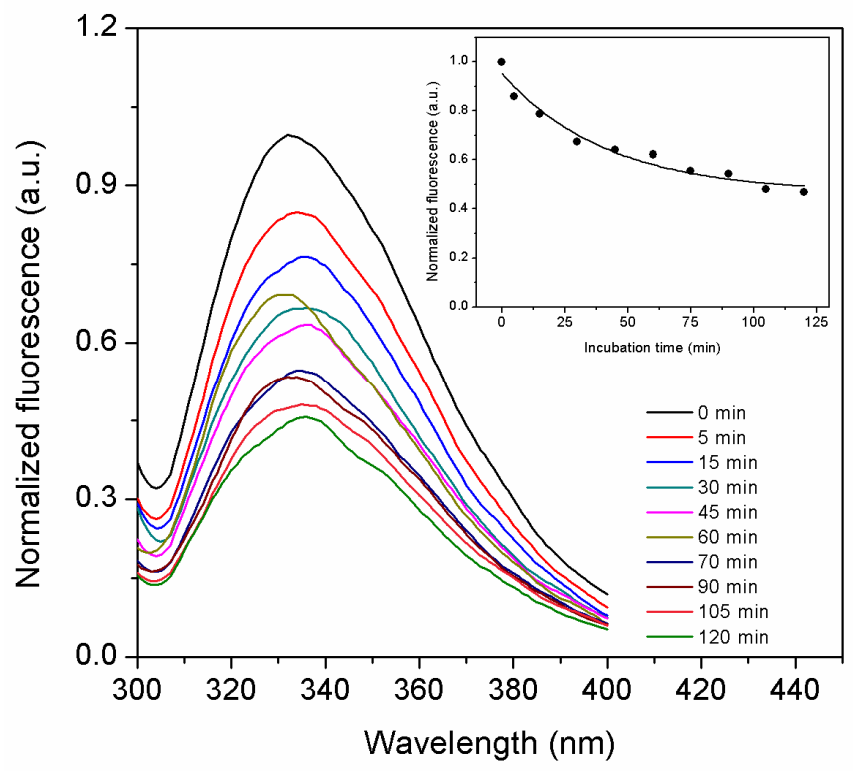

Fig. 3. Fluorescence spectra for skBADH incubated with $100 \mu \mathrm{M} \mathrm{H}_{2} \mathrm{O}_{2}$. Inset: SkBADH time dependent quenching. 
In addition, with respect to the maximum emission wavelength, no blue/red shift could be detected which suggests the direct alteration of the enzyme site rather than a change in protein folding, and which also rules out any enzyme denaturation.

\subsection{The effect of ligands on enzyme quenching provoked by hydrogen peroxide}

The skBADH fluorescence spectra at both $\mathrm{pH} 7.0$ and $\mathrm{pH} 8.0$ showed that the maximum emission and the wavelength at which the maxima occurred were equal (Fig. 4). Fluorescence spectral centers of mass changed between 1 and $2 \mathrm{~nm}$. At $\mathrm{pH}$ 7.0, hydrogen peroxide increased the enzyme's maximum emission but did not cause a blue or red shift (Fig. 4A). The presence of BA produced a red shift indicating a change in solvent exposition of tryptophans, caused by hydrogen peroxide and BA mix (Fig. 4A). However, the enzyme product GB had no effect on the quenching provoked by peroxide. At $\mathrm{pH} 8.0$, as before, skBADH fluorescence was quenched by hydrogen peroxide without any blue or red shift (Fig. 4B). BA and GB did not play a role in the enzyme fluorescence quenching induced by hydrogen peroxide (Fig. 4B).
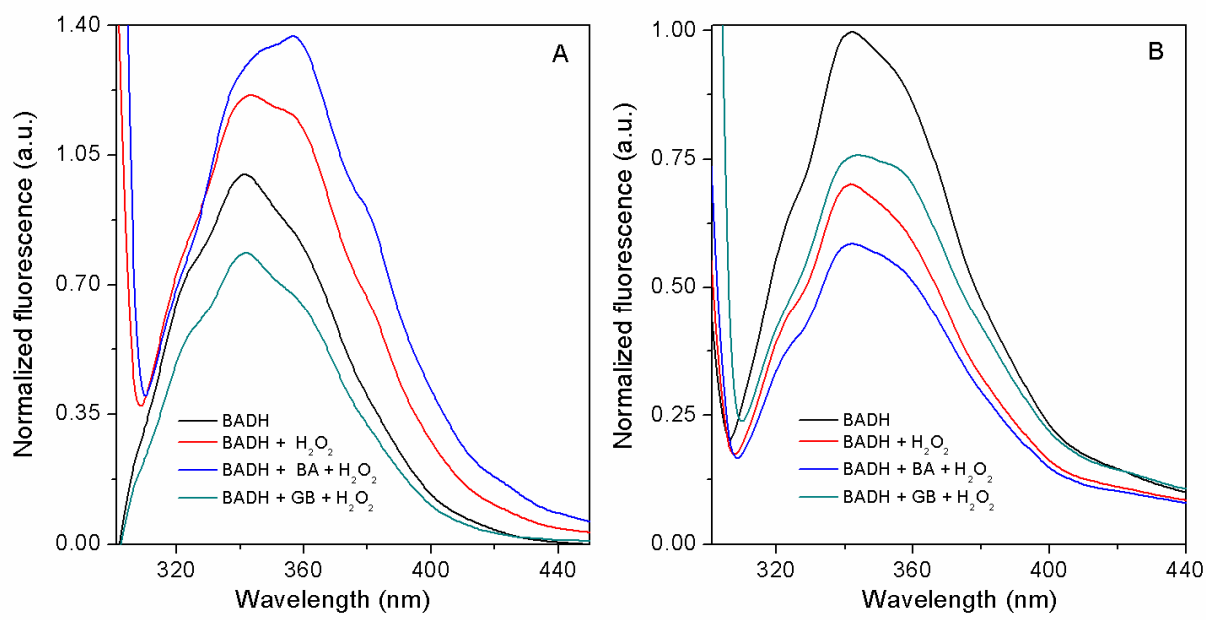

Fig. 4. Fluorescence spectra for skBADH incubated at $\mathrm{pH} 7.0$ (A) and $\mathrm{pH} 8.0$ (B) in the absence and presence of $100 \mu \mathrm{M} \mathrm{H}_{2} \mathrm{O}_{2}$, betaine aldehyde (BA) or glycine betaine (GB).

\subsection{The effect of copper on enzyme activity}

SkBADH incubated with $10 \mu \mathrm{M} \mathrm{CuCl}_{2}$ at $\mathrm{pH} 7.0$ and 8.0 was inactivated in a time dependent manner (Fig. 5). In assays performed at $\mathrm{pH} 8.0$, enzyme activity decreased 80\%, however when $\mathrm{KCl}$ was included in the incubation assay, enzyme activity decreased $45 \%$ (Fig. 5A). Data analysis revealed single exponential decay kinetics with $k_{\mathrm{obs}}=0.0112 \pm 0.005 \mathrm{~min}^{-1}$ for the enzyme incubated with $\mathrm{KCl}$ and $k_{\mathrm{obs}}=0.022 \pm 0.002 \mathrm{~min}^{-1}$ for the enzyme incubated without $\mathrm{KCl}$ (Fig. 5A).

The enzyme incubated with $10 \mu \mathrm{M} \mathrm{CuCl}_{2}$ at $\mathrm{pH} 7.0$ had a different inactivation pattern: skBADH lost $48 \%$ of its activity in absence of $\mathrm{KCl}$, whereas in its presence enzyme 
inactivation reached 59\% (Fig. 5B). The inactivation process follows single exponential decay kinetics with $k_{\mathrm{obs}}=0.0412 \pm 0.0057 \mathrm{~min}^{-1}$ for the enzyme incubated with $\mathrm{KCl}$ and $k_{\mathrm{obs}}=0.0147$ $\pm 0.0048 \mathrm{~min}^{-1}$ for the enzyme incubated without $\mathrm{KCl}$ (Fig. 5B). Under renal $\mathrm{pH}$ and ionic strength conditions skBADH is inactivated by copper concentrations that can occur in kidney.
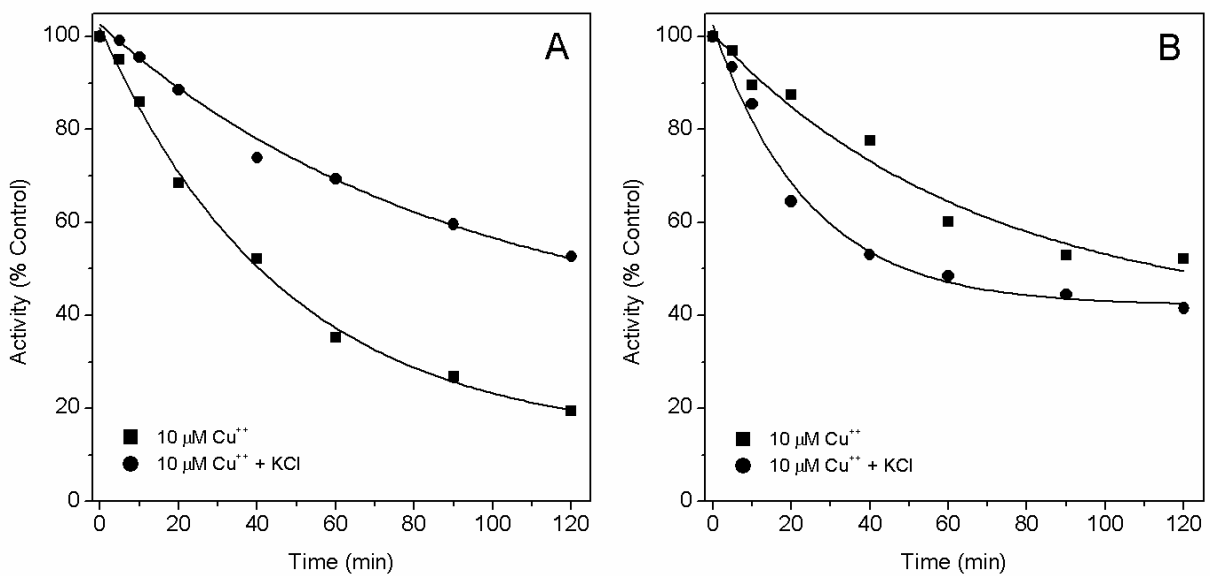

Fig. 5. Time courses of the inactivation of skBADH by copper. (A) Enzyme incubated in Hepes-KOH buffer at $\mathrm{pH}$ 8.0; (B) Enzyme incubated in Hepes- $\mathrm{KOH}$ buffer at $\mathrm{pH}$ 7.0. The lines are the best fit of the inactivation data to a single exponential decay equation.

\subsection{Enzyme reactivation kinetics}

The fully inactivated enzyme was incubated in the presence of $10 \mathrm{mM}$ DTT, $10 \mathrm{mM} \mathrm{GSH}$ or $10 \mathrm{mM}$ 2-mercaptoethanol. SkBADH incubated with DTT at $\mathrm{pH} 8.0$ or $\mathrm{pH} 7.0$ recovered $93 \%$ and $96 \%$ of its activity, respectively (Fig. 6). When the reducing agent used was 2mercaptoethanol, under conditions of $\mathrm{pH} 8.0$ or $\mathrm{pH} 7.0$ the enzyme recovered $86 \%$ and $84 \%$ of its activity (Fig. 6). With GSH at pH 8.0, skBADH recovered $90 \%$ of its activity (Fig. 6B), while at $\mathrm{pH} 7.0$ the enzyme recovered $30 \%$ of its activity (Fig. 6A). Enzyme recovery activity was faster at $\mathrm{pH} 8.0$ than at $\mathrm{pH} 7.0$, regardless of the reducing agent tested (Fig. 6). SkBADH incubated with reducing agents in the presence of $0.15 \mathrm{M} \mathrm{KCl}$ behaved very similarly to the curves in Figure 6 (data not shown). GSH was not able to recover enzyme activity when there was potassium in the assay medium. No significant skBADH activity changes were obtained after long incubation periods.

The failure of GSH to reactivate skBADH and other BADHs inactivated by thiol-specific reagents had been reported (Rosas-Rodríguez \& Valenzuela-Soto, 2011; Velasco-García et al., 2003; Vallari \& Pietruszko, 1982); however, the reason for this failure is not yet clear and may be related to the larger size of GSH, which prevents it from accessing the active site. 

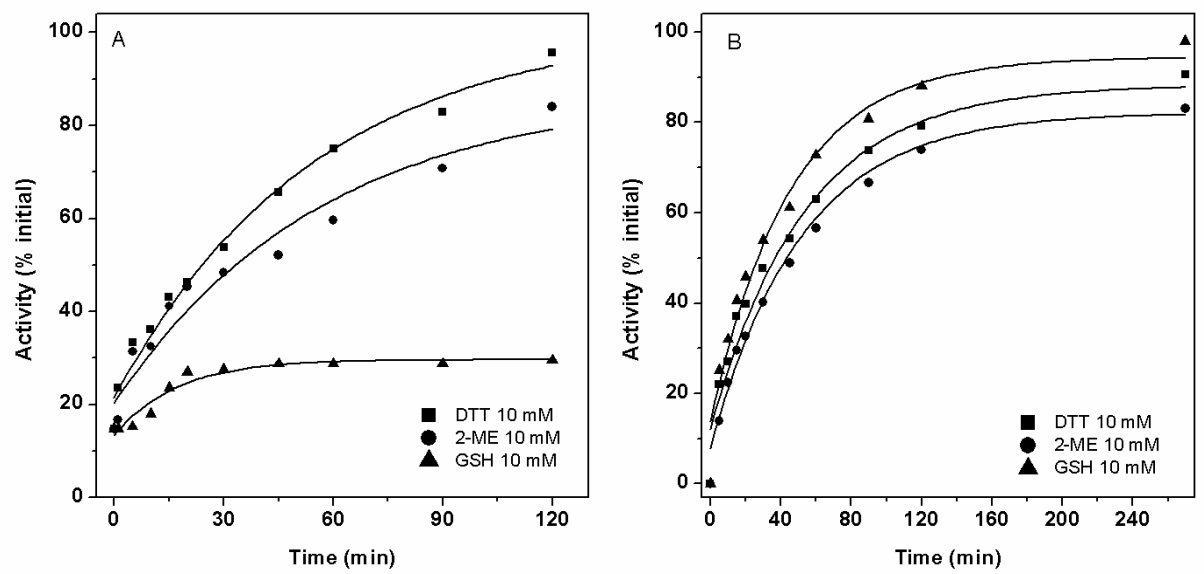

Fig. 6. Reactivation kinetics for skBADH inactivated by copper. Enzyme inactivated by 50 $\mu \mathrm{M} \mathrm{CuCl}_{2}$ to a residual activity of $15 \%$ over a 150 min reaction. Enzyme incubated: at $\mathrm{pH} 7.0$ (A) or $\mathrm{pH} 8.0$ (B). The lines are the best fit of the inactivation data to a single exponential decay equation.

\subsection{The effect of copper on enzyme fluorescence}

The skBADH fluorescence spectra were obtained from enzyme incubation assays with 10 $\mu \mathrm{M} \mathrm{CuCl}_{2}$ at $\mathrm{pH} 8.0$ or $\mathrm{pH}$ 7.0. Enzyme fluorescence was quenched by copper at both $\mathrm{pH}$ values (Fig. 7 and 8). Enzyme maximum emission changed with respect to the time of incubation at both $\mathrm{pH}$ values. However, incubation time did not have any effect on the wavelength at which maximum emission occurred.
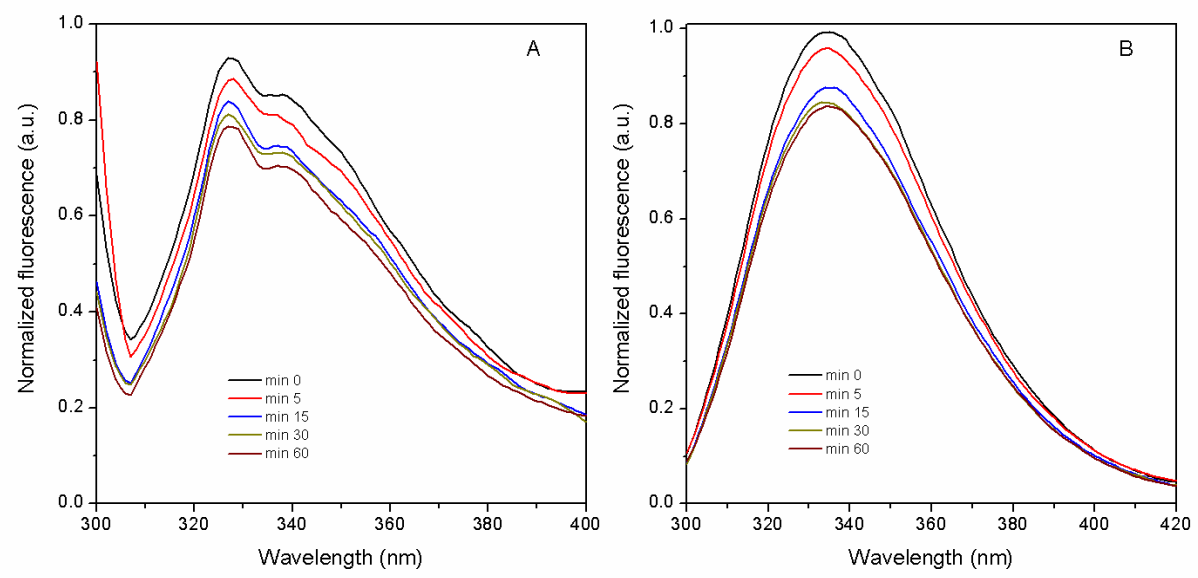

Fig. 7. The effect of copper and incubation time on skBADH fluorescence spectra. Enzyme incubated at $\mathrm{pH} 7.0$ with $10 \mu \mathrm{M} \mathrm{CuCl}_{2}$ (A), plus $0.15 \mathrm{M} \mathrm{KCl}(\mathrm{B})$. 
The drop in the enzyme's maximum emission was similar at both $\mathrm{pH}$ values, though the wavelength at which that maximum occurred was different at $\mathrm{pH} 7.0$ and $\mathrm{pH}$ 8.0. At $\mathrm{pH} 7.0$ the maximum emission wavelength for the enzyme incubated only with copper was $327 \mathrm{~nm}$ (Fig. 7A). Copper caused a blue shift in the enzyme, implying that the tryptophans were less exposed to the solvent. The presence of $0.15 \mathrm{M} \mathrm{KCl}$ reversed the blue shift (Fig 7B). The skBADH fluorescence spectra at $\mathrm{pH} 8.0$ with $10 \mu \mathrm{M} \mathrm{CuCl}_{2}$ did not exhibit a blue or red shift (Fig. 8A) and the presence of $\mathrm{KCl}$ did not cause any changes (Fig. 8B).
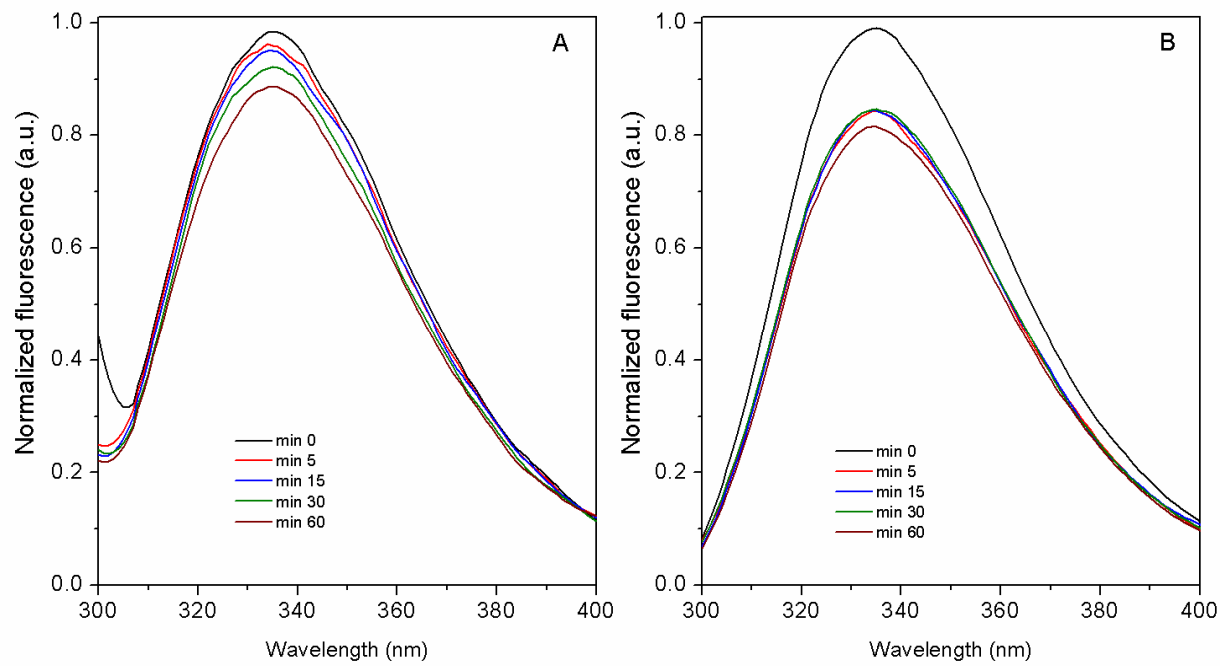

Fig. 8. The effect of copper and incubation time on skBADH fluorescence spectra. Enzyme incubated at $\mathrm{pH} 8.0$ with $10 \mu \mathrm{M} \mathrm{CuCl}_{2}$ (A), plus $0.15 \mathrm{M} \mathrm{KCl}(\mathrm{B})$.

\section{Discussion}

SkBADH has four tryptophan residues per subunit, which means there are sixteen residues in the enzyme's active conformation (tetramer), making Trp fluorescence a useful technique for structure-function studies. Alvarez et al. (2010) report that the presence of reactive oxygen species could impact the fluorescent properties of a specific protein (Cyan Fluorescent Protein), due to chemical modifications that cause changes in the chromophore pocket (Alvarez et al., 2010). These authors suggest that the alterations could be related to the torsion of amino acid residues, which leads to a quenching process.

The quenching of skBADH fluorescence by hydrogen peroxide is consistent with data reported by Tsourkas et al. (2005) who detected a 50\% decrease in fluorescent emission for Red Fluorescent Protein (DsRed) and 95\% for Enhanced Yellow Fluorescent Protein (EYFP) in the presence of $50 \mu \mathrm{M}$ hydrogen peroxide (Tsourkas et al., 2005). The authors attributed the quenching process to intramolecular cross-linking between two cysteines which puts stress on the protein structure (Tsourkas et al., 2005). 
A previous study reported that skBADH is inactivated by $\mathrm{H}_{2} \mathrm{O}_{2}$ in an oxygen independent modification process (Rosas-Rodríguez \& Valenzuela-Soto, 2011). Our data for enzyme fluorescence quenching by peroxide indicates that the protein's tertiary structure was not changed (Fig. 2). Together, the inactivation and fluorescence data support the idea that enzyme inactivation is caused by a disulfide bond between vicinal cysteines (C288-C289) at the active site, as previously postulated (Rosas-Rodríguez \& Valenzuela-Soto, 2011).

Based on the mechanism of the hydrogen peroxide and cysteine reaction (Luo \& Anderson, 2008), we propose a structural model showing the interaction of peroxide with the skBADH active site that leads to enzyme inactivation (Fig. 9). The structural model of skBADH was compared with that of methanol dehydrogenase ( $\mathrm{pdb} 1 \mathrm{~g} 72$ ) to look for type VIII folding, because that kind of folding has been found in proteins forming disulfide bridges between vicinal cysteines (Carugo et al., 2003). Both models were very similar, thus we think that skBADH exhibits the type VIII $\beta$-turn folding that allows for disulfide bridge formation.

Copper had the strongest inactivation effect on skBADH under physiological $\mathrm{pH}$ and ionic strength conditions (Fig. 5). Because the potassium concentrations in kidney medulla cells are those tested in this study, skBADH is a target for copper oxidation which leads to a decrease in glycine betaine synthesis and accumulation. In addition to its function as an osmolyte, glycine betaine functions as an osmoprotector (Rosas-Rodríguez et al., 2010); the insufficient osmoprotection and osmoregulation of renal cells may be related to some kidney pathologies.

The highest levels of BADH activity and protein occur in human liver, the adrenal gland, and kidney (Izaguirre et al, 1991). Besides of the role played by BADH in kidney, mammalian BADH catalyzes the oxidation of different amino aldehydes in addition to betaine aldehyde, so this enzyme is thought to be involved in: (i) the biosynthesis of GB, which may function as a methyl donor for methionine synthesis in liver (duVigneaud, 1946, Muntz, 1950), (ii) polyamine catabolism (Ambroziak \& Pietruszko, 1991), (iii) the synthesis of the inhibitory neurotransmitter $\gamma$-aminobutyrate (GABA) particularly in adrenal glands where putrescine is a source of $\gamma$-aminobutyric acid (Lin et al., 1996), and (iv) carnitine biosynthesis (Vaz et al., 2000). It is possible that all BADHs might be susceptible to copper inactivation, but it is important to conduct studies to test this idea.

SkBADH was inactivated by $10 \mu \mathrm{M} \mathrm{CuCl}_{2}$ as a consequence of its thiol groups being oxidized (Fig. 5). The oxidation process was reversed by thiol reducing agents, DTT and 2$\mathrm{ME}$ and GSH (at pH 8.0) (Fig. 6B), whereas at pH 7.0 DTT and 2-ME were able to restore enzyme activity which is consistent with the generation of a disulfide bond in the enzyme (Fig. 6A). A disulfide bond could be formed between Cys 288 and Cys 289 at the active site (Fig. 10). GSH was not able to restore enzyme activity at $\mathrm{pH} 7.0$, which suggests that GSH cannot prevent skBADH inactivation in vivo.

Inactivation by copper due to thiol oxidation has been observed for other enzymes such as rat and human aldose reductase, where inactivation results from disulfide bridge formation (Cecconi et al., 2002). Similarly, Hadizadeh et al. (2009) observed that the enzyme xanthine oxidase is inactivated by copper in a concentration and time dependent manner (Hadizadeh et al. 2009). 
(1)

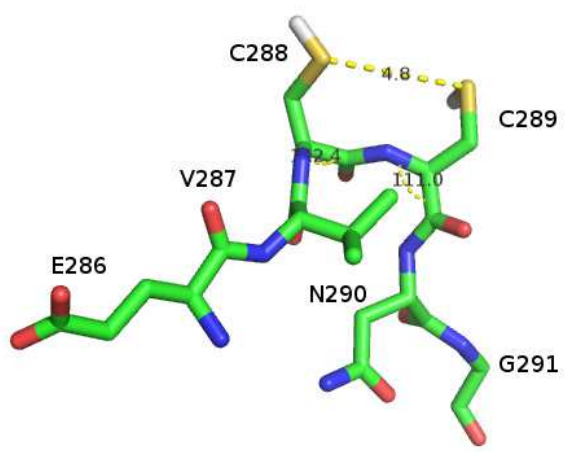

(2)

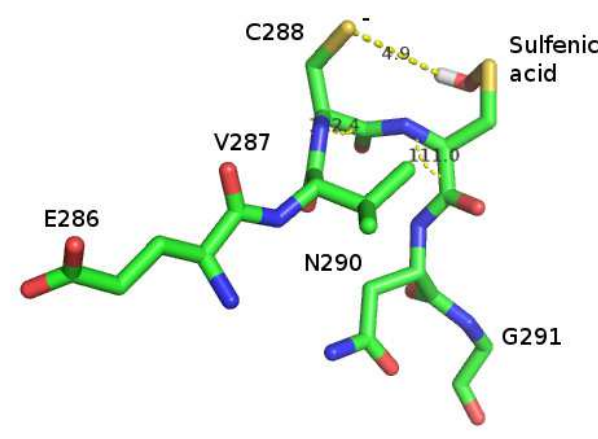

(3)

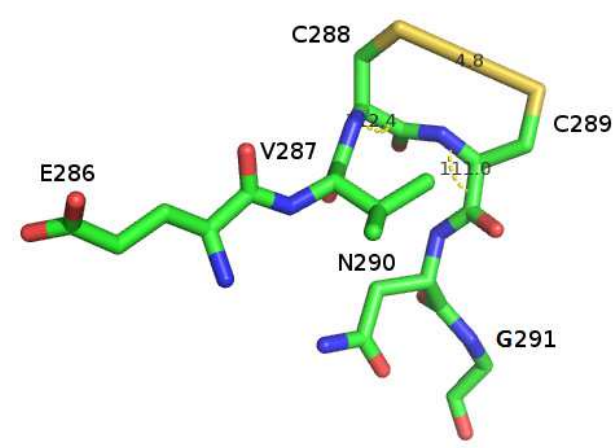

Fig. 9. Proposed mechanism for the reaction of the skBADH active site and $\mathrm{H}_{2} \mathrm{O}_{2}$. Hydrogen peroxide reacts with the thiol group $(\mathrm{CSH})$ of the catalytic cysteine $(\mathrm{C} 288)$ or the vicinal cysteine (C289) (1) leading to sulfenic acid formation (RSOH) (2), the proximity of a second thiolate group allows the intermediate sulfenic acid to combine with the thiolate group and form a disulfide bond (RSSR) between cysteines (3). 
A
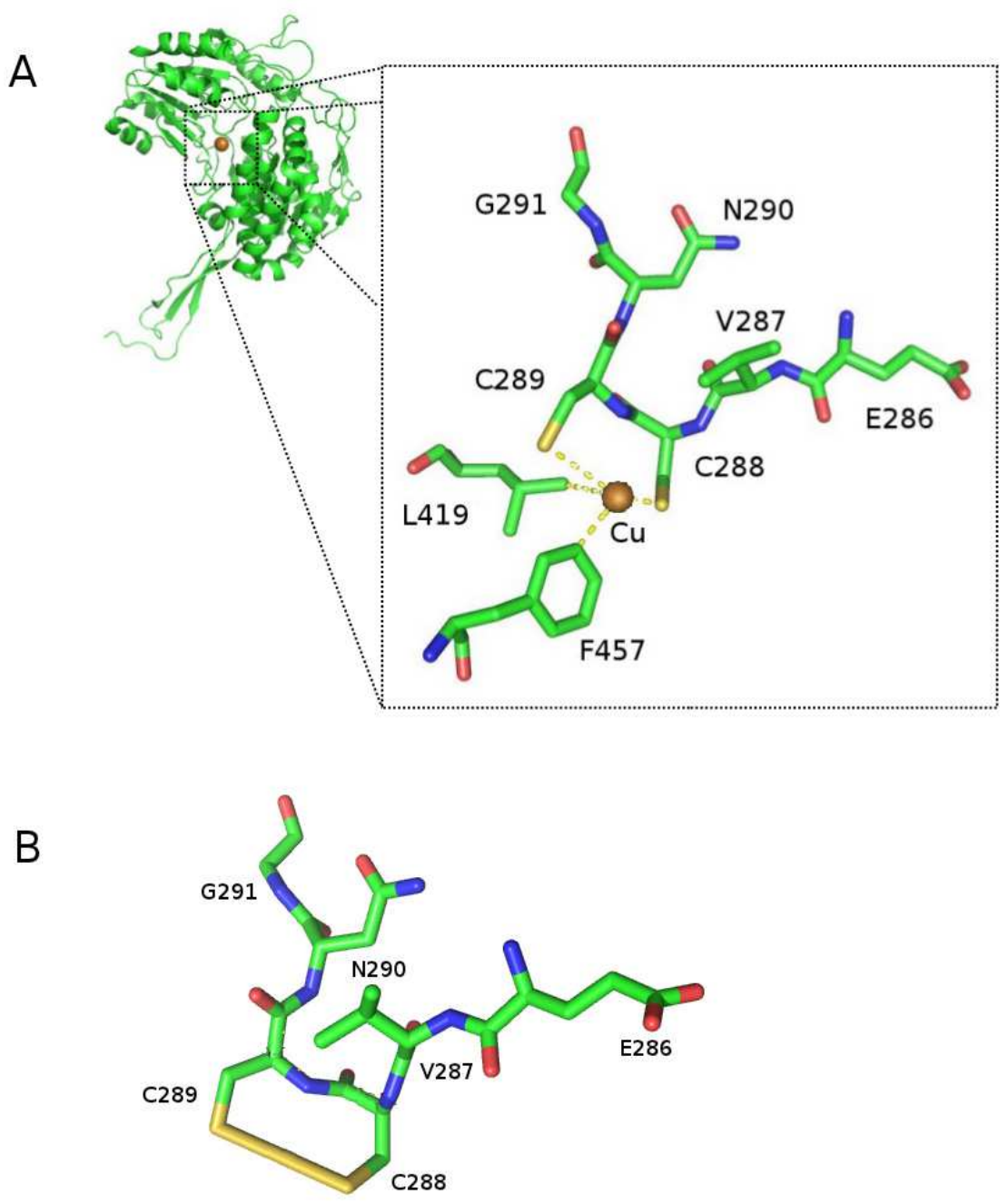

Fig. 10. Proposed mechanism for the reaction of the sKBADH active site and copper. Copper reacts with the thiol group $(\mathrm{CSH})$ of the catalytic cysteine $(\mathrm{C} 288)$ or the vicinal cysteine (C289) (A), leading to the formation of a disulfide bond (RSSR) between cysteines (B).

SkBADH fluorescence spectra with $10 \mu \mathrm{M} \mathrm{CuCl}_{2}$ at $\mathrm{pH} 7.0$ and $\mathrm{pH} 8.0$ exhibited differences in the wavelengths at which the maximum emission occurred (Fig. 7 and 8), demonstrating that copper is changing the tryptophans' access to the solvent. In addition, potassium seems to be playing an interesting role in exposing the tryptophans in the enzyme to the solvent. Previous studies have demonstrated that skBADH requires a monovalent cation to maintain its tetrameric conformation (Valenzuela-Soto et al., 2003). SkBADH crystallographic studies are needed to see whether there is a site on the enzyme for potassium or for a different monovalent cation, such as that found in P. aeruginosa BADH (González-Segura et al., 2009). 
Further studies are underway to determine if skBADH inactivation is dependent on copper concentration, to identify the time course of disulfide generation, and to detect whether there are differences in inactivation when $\mathrm{Cu}(\mathrm{I})$ or $\mathrm{Cu}(\mathrm{II})$ is used in the treatments.

\section{Conclusion}

SkBADH was oxidized by hydrogen peroxide and by copper at concentrations that likely reflect physiologically relevant conditions (Atmane et al. 2003; Caselli et al. 1998; Kazi et al., 2008; Meng et al. 2002; Pravodh et al. 2011) in kidney, and the targets of oxidation were thiol groups, mainly those of the active site. Interestingly, the thiol groups were not oxidized to sulfenic or sulfinic acid, but rather a disulfide bond was formed between catalytic cysteine (Cys288) and a vicinal cysteine (C289). Potassium, under physiological conditions, increased the oxidation of the enzyme by copper, possibly because it maintains the enzyme active tetramer or enables the oxidation of the cysteine residues. Since GB synthesis is catalyzed by BADH and it is crucial for the kidney cells to be able to withstand osmotic stress conditions, this type of inhibition can have serious physiological implications. In addition, BADH is an enzyme that is also found in the liver and brain where its inactivation by oxidative stress is associated with other pathologies. In summary, identifying the specific modifications caused by ROS on key enzymes contributes to a greater understanding of the changes that occur during oxidative stress and provides insight into how oxidative stress can be prevented. Further work is underway to determine the mechanisms by which renal BADH can be protected from the oxidative stress that occurs in renal medulla cells.

\section{Perspectives}

Hydrogen peroxide plays a role as an oxidant and as a secondary messenger, however the molecular basis of these roles and the concentration of $\mathrm{H}_{2} \mathrm{O}_{2}$ in cells has not been established. In addition, copper can interact with proteins, causing oxidation, or can generate oxidative stress. In light of this it is important to pursue this line of research, also because hydrogen peroxide and copper have been associated with some human pathologies that are characterized by some interaction between hydrogen peroxide and copper and enzymes and proteins. This opens up new areas for developing strategies to contend with some of the diseases directly related to oxidative stress.

\section{Acknowledgments}

This study was supported by the Consejo Nacional de Ciencia y Tecnología (CONACYT). HFFM received a graduate scholarship from CONACYT. JARR is grateful for support from "Apoyos Complementarios para la Consolidación Institucional de Grupos de Investigación: Retención 149021" awarded by CONACYT. The authors are grateful to Bianca Delfosse, who improved the English.

\section{References}

Ambroziak, W., \& Pietruszko, R. (1991) Human aldehyde dehydrogenase. Activity with aldehyde metabolites of monoamines, diamines, and polyamines. Journal of Biological Chemistry, Vol.266, No.20, (July 1991), 13011-13018, ISSN 0021-924. 
Alvarez, L., Levin, C.H., Merola, F., Bizouarn, T., Pasquier, H., Baciou, L., Rusconi, F., \& Erard, M. (2010). Are the fluorescent properties of the cyan fluorescent protein sensitive to conditions of oxidative stress? Photochemistry and Photobiology, Vol.86, No.1, (January-February 2010), 55-61, ISSN 1751-1097.

Arakawa, K., Takabe, T., Sugiyama, T., \& Akazawa, T. (1987). Purification of betainealdehyde dehydrogenase from spinach leaves and preparation of its antibody. The Journal of Biochemistry, Vol.101, No.6, (December 1987), 1485-1488, ISSN 0021-924.

Atmane, N., Dairou, J., Paul, A., Dupret, J-M., \& Rodrigues-Lima, F. (2003). Redox Regulation of the Human Xenobiotic Metabolizing Enzyme Arylamine NAcetyltransferase 1 (NAT1). Journal of Biological Chemistry, Vol.278, No.37, (September 2003), 35086-35092, ISSN 0021-9258.

Banday, A.A., \& Lokhandwala, M.F. (2011). Oxidative stress causes renal angiotensin II type 1 receptor upregulation, $\mathrm{Na}^{+} / \mathrm{H}^{+}$exchanger 3 overstimulation, and hypertension. Hypertension, Vol.57, No.2, (March 2011), 452-459, ISSN 0194-911.

Boch, J., Nau-Wagner, G., Kneip, S., \& Bremer, E. (1997). Glycine betaine aldehyde dehydrogenase from Bacillus subtilis: characterization of an anzyme required for the synthesis of the osmoprotectant glycine betaine. Archives of Microbiology, Vol.168, No.4, (September 1997), 282-289, ISSN 1432-072.

Bonda, D.J., Lee, H., Blair, J.A., Zhu, X., Perry, G., \& Smith, M.A. (2011) Role of metal dyshomeostasis in Alzheimer's disease. Metallomics, Vol.3, No.3, (March 2011), 267270, ISSN 1756-5901.

Burg, M.B., \& Ferraris J.D. (2008). Intracellular organic osmolytes: function and regulation. Journal of Biological Chemistry, Vol. 283, No.12, (March 2008), 7309-7313, ISSN 00219258.

Burg, M.B., Dmitrieva N.I. \& Ferraris J.D. (2007). Cellular response to hyperosmotic stresses. Physiological Reviews, Vol.87, No.4 , (October 2007), 1441-1474, ISSN 0031-9333.

Burg, M.B., Kwon, E.D., \& Peters, E.M. (1996). Glycerophosphocholine and betaine counteract the effect of urea on pyruvate kinase. Kidney International, Vol.50, No.57, (December 1996), S100-104, ISSN 0085-2538.

Burkitt, M.J. (2001) A Critical Overview of the Chemistry of Copper-Dependent Low Density Lipoprotein Oxidation: Roles of Lipid Hydroperoxides, a-Tocopherol, Thiols, and Ceruloplasmin. Archives of Biochemistry and Biophysics, Vol.394, No.1, (1 October 2001), 117-135, ISSN 0003-9861.

Butterworth, R.F. (2010). Metal toxicity, liver disease and neurodegeneration. Neurotoxicity Research, Vol.18, No.1, (July 2010), 100-105, ISSN 1029-8428.

Carugo, O., Čemažar, M., Zahariev, S., Hudáky, I., Gáspári, Z., Perczel, A., \& Pongor, S. (2003) Vicinal disulfide turns. Protein Engineering, Vol.16, No.9, (September 2003), 637-639, ISSN 1741-0126.

Caselli, A., Marzocchini, R., Camici, G., Manao, G., Moneti, G., Pieraccini, G., \& Ramponi, G. (1998). The inactivation mechanism of low molecular weight phosphotyrosineprotein phosphatase by $\mathrm{H}_{2} \mathrm{O}_{2}$. Journal of Biological Chemistry, Vol.273, No.49, (December 1998), 32554-32560, ISSN 0021-9258.

Cecconi, I., Scalon, A., Rastelli, G., Moroni, M., Vilardo, P., Costantino, L., Cappiello, M., Garland, D., Carper, D., Petrash, J., Del Corso, A., \& Mura, U. (2002). Oxidative modification of aldose reductase induced by copper ion. Journal of Biological Chemistry, Vol.277, No.44, (November 2002), 42017-42027, ISSN 0021-9258. 
Chen, T.H.H., \& Murata, N. (2011). Glycinebetaine protects plants against abiotic stress: mechanisms and biotechnological applications. Plant, Cell and Environment, Vol. 34, No.1, (January 2011), 1-20, ISSN 1365-3040

Chern, M.K., \& Pietruzko R. (1999). Evidence for mitochondrial localization of betaine aldehyde dehydrogenase in rat liver: purification, characterization, and comparison with human cytoplasmic E3 isozyme. Biochemistry and Cell Biology, Vol.77, No.3, (July 1999), 179-187. ISSN 0829-8211.

Coughlan, M.T., Thorburn, D.R., Penfold, S.A., Laskowski, A., Harcourt, B.E., Sourris, K.C., Tan, A.L.Y., Fukami, K., Thallas-Bonke, V., Nawroth, P.P., Brownlee, M., Bierhaus, A., Cooper, M.E., \& Forbes, J.M. (2009) RAGE-Induced Cytosolic ROS Promote Mitochondrial Superoxide Generation in Diabetes. Journal of the American Society of Nephrology, Vol.20, No.4, (April 2009), 742-752, ISSN 1046-6673.

Coyle, C.H., Martinez, L.J., Coleman. M.C., Spitz, D.R., Weintraub, N.L., \& Kader, K.N. (2006) Mechanisms of $\mathrm{H}_{2} \mathrm{O}_{2}$-induced oxidative stress in endothelial cells. Free Radical Biology $\mathcal{E}$ Medicine, Vol.40, No. 12, (15 June 2006), 2206-2213, ISSN 0891-5849.

Diamant, S., Eliahu, N., Rosenthal, D., \& Goloubinoff, P. (2001). Chemical chaperones regulate molecular chaperones in vitro and in cells under combined salt and heat stresses. Journal of Biological Chemistry, Vol.276, No.43, (October 2001), 39586-39591, ISSN 0021-9258.

du Vigneaud, V., Simmonds, S., Chandler, J.P., \& Cohn, M. (1946). A further investigation of the role of betaine in transmethylation reactions in vivo. Journal of Biological Chemistry, Vol.165, No.2, (October 1946), 639-648, ISSN 0021-9258.

Elumalai, M., Antunes, C., \& Guilhermino, L. (2002). Effects of single metals and their mixtures on selected enzymes of Carcinus maenas. Water, Air, $\mathcal{E}$ Soil Pollution, Vol.141, No.3, (November 2002), 273-280, ISSN 0049-6979.

Falkenberg, P., \& Strom, A.R. (1990). Purification and characterization of osmoregulatory betaine aldehyde deshydrogenase of Escherichia coli. Biochimica et Biophysica Acta, Vol.1034, No.3, (June 1990), 253-259, ISSN 006-3002.

Figueroa-Soto, C.G., \& Valenzuela-Soto, E.M. (2001). Purification of a heterodimeric betaine aldehyde dehydrogenase from wild amaranth plants subjected to water deficit. Biochemical and Biophysical Research Communications, Vol.285, No.4, (July 2001), 10521058, ISSN 0006-291.

Figueroa-Soto, C.G., \& Valenzuela-Soto, E.M. (2000). Kinetic study of porcine kidney betaine aldehyde dehydrogenase. Biochemical and Biophysical Research Communications, Vol,269, No.2, (March 2000), 596-603 ISSN 0006-291.

Forbes, J. M., Coughlan M.T., \& Cooper M.E. (2008). Oxidative stress as a major culprit in kidney disease in diabetes. Diabetes, Vol.57, No.6, (June 2008), 1446-1454, ISSN 0012-1797.

Ganesan, B., Buddhan, S., Anandan R., Sivakumar R., \& AnbinEzhilan R. (2010). Antioxidant defense of betaine against isoprenaline-induced myocardial infarction in rats. Molecular Biology Reports, Vol.37, No.3, (March 2010), 1319-1327, ISSN 1573-4978.

Giles, N.M., Watts, A.B., Giles, G.I., Fry, F.H., Littlechild, J.A., \& Jacob C. (2003). Metal and Redox Modulation Review of Cysteine Protein Function. Chemistry and Biology, Vol.10, No.10, (August 2003), 677-693, ISSN 1074-5521.

Go, E.K., Jung, K.J., Kim J.Y., Yu B.P., \& Chung, H. (2005). Betaine suppresses proinflammatory signaling during aging: the involvement of nuclear factor- 
KappaB via nuclear factor-inducing kinase/IKappaB kinase and mitogen-activated protein kinases. Journals of Gerontology Series A: Biological Sciences and Medical Sciences, Vol.60A, No.10, (October 2005), 1252-1264, ISSN 1079-5006.

González-Segura, L., Rudiño-Piñera, E., Muñoz-Clares, R.A., \& Horjales, E. (2009). The crystal structure of a ternary complex of betaine aldehyde dehydrogenase from Pseudomonas aeruginosa provides new insight into the reaction mechanisms and shows a novel binding mode of the 2'-phosphate of NADP+ and a novel cation binding site. Journal of Molecular Biology, Vol.385, No.2, (January 2009), 542-557, ISSN 0022-2836.

González-Segura, L., Velasco-García, R., \& Muñoz-Clares, R.A. (2002). Modulation of the reactivity of the essential cysteine residue of betaine aldehyde dehydrogenase from Pseudomonas aeruginosa. Biochemical Journal, Vol.361, No.3, (February 2002), 577-585, ISSN 1264-6021.

Graf, D., Kurz, A.K., Reinehr, R., Fischer, R., Kircheis, G., \& Häussinger, D. (2002). Prevention of bile acid-induced apoptosis by betaine in rat liver. Hepatology, Vol.36, No.4, (November 2002), 829-839, ISSN 1665-2681.

Guzman-Partida, A.M., \& Valenzuela-Soto, E.M. (1998). Porcine kidney betaine aldehyde dehydrogenase: purification and properties. Comparative Biochemistry and Physiology, Part B, Vol.119, No.3, (March 1998), 485-491, ISSN 1096-4959.

Hadizadeh, M., Keyhani, E., Keyhani, J., \& Khodadadi, C. (2009). Functional and structural alterations induced by copper in xanthine oxidase. Acta Biochimica et Biophysica Sinica, Vol.41, No.7, (July 2009), 603-617, ISSN 1672-9145.

Halliwell, B. (2007) Biochemistry of oxidative stress. Biochemical Society Transactions, Vol.35, No.5, (November 2007), 1147-1150, ISSN 0300-5127.

Harper, M., Bevilacqua, L., Hagopian, K., Weindruch, R., \& Ramsey, J. (2004). Ageing, oxidative stress, and mitochondrial uncoupling. Acta Physiologica Scandinavica, Vol.182, No.4, (August 2004), 321-331, ISSN 001-6772.

Hjelmqvist, L., Norin, A., El-Ahmad, M., Griffiths, W. J., \& Jornvall, H. (2003). Distinct but parallel evolutionary patterns between alcohol and aldehyde dehydrogenases: addition of fish/human betaine aldehyde dehydrogenase divergence, Cellular and Molecular Life Sciences, Vol.60, No.9, (September 2003), 2009-2016, ISSN 1420-682.

Izaguirre, G., Kikonyogo, A., \& Pietruszko, R. (1997). Tissue distribution of human aldehyde dehydrogenase E3 (ALDH9): comparison of enzyme activity with E3 protein and mRNA distribution. Comparative Biochemistry and Physiology, Part B, Vol.118, No.1, (February 2003), 59-64, ISSN 1096-4959.

Jomova, K., \& Valko, M. (2011). Advances in metal-induced oxidative stress and human disease. Toxicology, Vol.283, No.2-3, (May 2011), 65-87, ISSN 0300-483X.

Jomova, K., Vondrakova, D., Lawson, M., \& Valko, M. (2010). Metals, oxidative stress and neurodegenerative disorders. Molecular and Cellular Biochemistry, Vol.345, No.1, (December 2010), 91-104, ISSN 0300-8177.

Julián-Sánchez, A., Riveros-Rosas, H., Martínez-Castilla, L.P., Velasco-García, R., \& MuñozClares, R.A. (2007). Phylogenetic and structural relationships of the betaine aldehyde dehydrogenases. In: Enzymology and Molecular Biology of Carbonyl Metabolism 13, H. Weiner, B. Plapp, R. Lindahl, E. Maser, (Eds), pp 64-76, Purdue University Press, ISBN 978-1-55753-447-7. 
Kazi, T., Afridi, H., Kazi, N., Jamali, M., Arain, M., Jalbani, N., \& Kandhro, G. (2008) Copper, chromium, manganese, iron, nickel, and zinc levels in biological samples of diabetes mellitus patients. Biological Trace Element Research, Vol.122, No.1, (April 2008), 1-18, ISSN 0163-4984.

Kurys, G., Ambroziak, W., \& Pietruszko, R. (1989). Human aldehyde dehydrogenase. Purification and characterization of a third with low $K_{m}$ for gammaaminobutyraldehyde. Journal of Biological Chemistry, Vol.264, No.8, (March 1989), 4715-4721, ISSN 0021-9258.

Kwon, M.S., Lim, S.W., \& Kwon, H.M. (2009). Hypertonic stress in the kidney: a necessary evil. Physiology, Vol.24, No.3, (June 2009), 186-191, ISSN 1548-9213.

Letelier, M.E., Martínez, M., González-Lira, V., Faúndez, M., \& Aracena-Parks, P. (2006). Inhibition of cytosolic glutathione S-transferase activity from rat liver by copper. Chemico-Biological Interactions, Vol.164, No.1-2, (December 2006), 39-48, ISSN 00092797.

Letelier, M.E., Lepe, A. M., Faúndez, M., Salazar, J., Marín, R., Aracena, P., \& Speisky, H. (2005). Possible mechanisms underlying copper-induced damage in biological membranes leading to cellular toxicity. Chemico-Biological Interactions, Vol.151, No.2, (January 2005), 71-82, ISSN 0009-2797.

Lin, S.W., Chen, J.C., Hsu, L.C. Hsieh, C.L., Yoshida, A. (1996). Human gammaaminobutyraldehyde dehydrogenase (ALDH9): cDNA sequence, genomic organization, polymorphysm, chromosomal localization, and tissue expression. Genomics, Vol.34, No.3, (June 1996), 376-380, ISSN 0888-7543.

Livingstone, J.R., Maruo. T., Yoshida, I. , Tarui, Y., Hirooka, K., Yamamoto, Y., Tsutui, N., \& Hirasawa, E. (2003). Purification and properties of betaine aldehyde dehydrogenase from Avena sativa. Journal of Plant Research, Vol.116, No.2, (April 2003), 133-140, ISSN 0918-9440.

Luo, D., \& Anderson, B.D. (2008). Application of a two-state kinetic model to the heterogeneous kinetics of reaction between cysteine and hydrogen peroxide in amorphous lyophiles. Journal of Pharmaceutical Sciences, Vol.97, No.9, (September 2008), 3907-3926, ISSN 0022-3549.

Lushchak, V.I. (2011) Adaptive response to oxidative stress: Bacteria, fungi, plants and animals. Comparative Biochemistry and Physiology Part C: Toxicology \& Pharmacology, Vol.153, No.2, (March 2011), 175-190, ISSN 1532-0456.

Martin, C.J., \& Goeddeke-Merickel, C.M. (2005). Oxidative stress in chronic kidney disease. Nephrology Nursing Journal, Vol.32, No.6, (November 2005), 683-685, ISSN 1526-744X.

Mattie, M.D., \& Freedman, J.H. (2004). Copper-inducible transcription: regulation by metaland oxidative stressresponsive pathways. American Journal Physiology and Cell Physiology, Vol.286, No.2, (February 2004), C293-C301, ISSN 0363-6143.

Meng, T-C., Fukada, T., \& Tonks, N.K. (2002). Reversible Oxidation and Inactivation of Protein Tyrosine Phosphatases In Vivo. Molecular Cell, Vol.9, No.2, (February 2002), 387-399, ISSN 1097-2765.

Mori, T., \& Cowley, A.W. Jr. (2003). Angiotensin II-NAD(P)H Oxidase-stimulated superoxide modifies tubulovascular nitric oxide cross-talk in renal outer medulla. Hypertension, Vol.42, No.4, (October 2003), 588-593, ISSN 0194-911. 
Mori, N., Yoshida, N., \& Kitamoto, Y. (1992). Purification and properties of betaine aldehyde dehydrogenase from Xanthomonas translucens. Journal of Fermentation and Bioengineering, Vol.73, No.5, (July 1992), 352-356, ISSN 0922-338X.

Mori, N., Kawakami, B., Hyakutome, K., Tani Y., \& Yamada, H. (1980). Characterization of betaine aldehyde dehydrogenase from Cylindrocarpon didymun M-1. Agricultural Biology and Chemistry, Vol.44, No.12, (December 1980), 3015-3016, ISSN 0002-1369.

Muntz, J.A. (1950). The inability of choline to transfer a methyl group directly to homocysteine for methionine formation, Journal of Biological Chemistry, Vol.182, No.2, (February 1950), 489-499, ISSN 0021-9258.

Muñoz-Clares, R.A., Díaz-Sánchez, A.G., González-Segura, L., \& Montiel, C. (2010). Kinetic and structural features of betaine aldehyde dehydrogenases: Mechanistic and regulatory implications. Archives of Biochemistry and Biophysics, Vol.493, No.1, (January 2010), 71-81, ISSN 003-9861.

Muñoz-Clares, R.A., \& Valenzuela-Soto, E.M. (2008). Betaine aldehyde dehydrogenases: evolution, physiological functions, mechanism, kinetics, regulation, structure, and stability. In: Advances in Protein Physical Chemistry, E. García-Hernández \& D.A. Fernández-Velasco, (Eds), pp 279-302, Research SignPost, ISBN 978-81-7895-324-3, Kerala, India.

Muñoz-Clares, R.A., González-Segura, L., Mújica-Jiménez, C., \& Contreras-Díaz, L. (2003). Ligand-induced conformational changes of betaine aldehyde dehydrogenase from Pseudomonas aeruginosa and Amaranthus hypochondriacus L. leaves affecting the reactivity of the catalytic thiol. Chemico-Biological Interactions, Vol.143-144, No.3, (Februry 2003), 129-137, ISSN 0009-2797.

Nagasawa, T., Kawabata, Y., Tani, Y., \& Ogata, K. (1976). Purification and characterization of betaine aldehyde dehydrogenase from Pseudomona aeruginosa A-16. Agricultural Biology and Chemistry, Vol.40, No.9, (September 1976), 1743-1749, ISSN 0002-1369.

Neuhofer, W., \& Beck, F.X. (2006). Survival in hostile environment: strategies of renal medullary cells. Physiology, Vol. 21, No.3, (June 2003), 171-180, ISSN 1548-9213.

Oishi, H., \& Ebina, M. (2005). Isolation of cDNA and enzymatic properties of betaine aldehyde dehydrogenase from Zoysia tenuifolia. Journal of Plant Physiology, Vol.162, No.10, (October), 1077-1086, ISSN 0176-1617.

Pan, S.M. (1988). Betaine aldehyde dehydrogenase in spinach. Botanical Bulletin of Academia Sinica, Vol.29, No.4, (October 1988), 255-263, ISSN 006-8063.

Prabodh, S., Prakash, D., Sudhakar, G., Chowdary, N., Desai, V., \& Shekhar, R. (2011) Status of copper and magnesium levels in diabetic nephropathy cases: a case-control study from South India. Biological Trace Element Research, Vol.142, No.1, (July 2011), 29-35, ISSN 0163-4989.

Prousek, J. (2007). Fenton chemistry in biology and medicine. Pure and Applied_Chemistry, Vol.79, No.12, (December 2007), 2325-2338, ISSN 0033-4545.

Prudent, M., \& Girault, H.H. (2009) The role of copper in cysteine oxidation: study of intraand inter-molecular reactions in mass spectrometry. Metallomics, Vol.1, No.2, (March 2009), 157-165, ISSN 1756-5901.

Rhee, S.G., Chang, T.-S., Bae, Y.S., Lee, S-R., \& Kang, S.W. (2003). Cellular regulation by hydrogen peroxide. Journal of American Society Nephrology, Vol.14, No.3, (August 2003), S211-215, ISSN 1533-3450. 
Rosas-Rodríguez, J.A., \& Valenzuela-Soto, E.M. (2011). Inactivation of porcine kidney betaine aldehyde dehydrogenase by hydrogen peroxide. Chemico-Biological Interactions, Vol.191, No.1-3, (May 2011), 159-164, ISSN 0009-2797.

Rosas-Rodríguez, J.A., Figueroa-Soto, C.G., \& Valenzuela-Soto, E.M. (2010). Inhibition of porcine kidney betaine aldehyde dehydrogenase by hydrogen peroxide. Redox Report, Vol.15, No.6, (December 2010), 282-287, ISSN 1351-0002.

Rothschild, H.A., \& Guzman-Barron, E.S. (1954). The oxidation of betaine aldehyde dehydrogenase. Journal of Biological Chemistry, Vol.209, (August 1954), 511-523, ISSN 0021-9258.

Salazar-Medina, A.J., García-Rico, L., García-Orozco, K.D., Valenzuela-Soto, E.M., Contreras-Vergara, C.A., Arreola, R., Arvizu-Flores, A., \& Sotelo-Mundo, R.R. (2010). Inhibition by $\mathrm{Cu} 2+$ and $\mathrm{Cd} 2+$ of a mu-class glutathione S-transferase from shrimp Litopenaeus vannamei. Journal of Biochemical and Molecular Toxicology, Vol.24, No.4, (August 2010), 218-222, ISSN 1099-0461.

Speisky, H., Gómez, M., Burgos-Bravo, F., López-Alarcón, C., Jullian, C., Olea-Azar, C., \& Aliaga, M.E. (2009). Generation of superoxide radicals by copper-glutathione complexes: Redox-consequences associated with their interaction with reduced glutathione. Bioorganic \& Medicinal Chemistry, Vol.17, No.5, (March 2009), 18031810, ISSN 0968-0896.

Steinebach, O.M., \& Wolterbeek, H.T. (1994). Role of cytosolic copper, metallothionein and glutathione in copper toxicity in rat hepatoma tissue culture cells. Toxicology, Vol.92, No.1-3, (September 1994), 75-90, ISSN 0300-483X.

Thengchaisri, N., \& Kuo, L. (2003) Hydrogen peroxide induces endothelium-dependent and -independent coronary arteriolar dilation: role of cyclooxygenase and potassium channels. American Journal of Physiology-Heart and Circulatory Physiology, Vol.285, No.6, (December 2003), H2255-H2263, ISSN 0363-6135.

Touyz, R.M. (2004). Reactive oxygen species, vascular oxidative stress, and redox signaling in hypertension: what is the clinical significance? Hypertension, Vol.44, No.3, (September 2004), 248-252, ISSN 0194-911X.

Touyz, R.M., \& Briones, A.M. (2011) Reactive oxygen species and vascular biology: implications in human hypertension. Hypertension Research, Vol.34, No.1, (January 2011), 5-14, ISSN 0916-9636.

Tsourkas, A.N.G., Perez, J.M., Basilion, J.P. \& Weissleder, R. (2005). Detection of peroxidase/H2O2-mediated oxidation with enhanced yellow fluorescent protein. Analytical Chemistry, Vol.77, No.9, (May 2005), 2862-2867, ISSN 0003-2700.

Umenishi, F., Yoshihara, S., Narikiyo, T., \& Schrier, R.W. (2005). Modulation of hypertonicity-induced aquaporin-1 by sodium chloride, urea, betaine, and heat shock in murine renal medullary cells. Journal of the American Society of Nephrology, Vol.16, No.3, (March 2005), 600-607, ISSN 1533-3450.

Valenzuela-Soto, E. M., Ayala-Castro, H.G., \& Muñoz-Clares, R.A., (2005). Effects of monovalent and divalent cations on the thermostability of mammal betaine aldehyde dehydrogenase. In: Enzymology and Molecular Biology of Carbonyl Metabolism 12. B. Plapp., E. Maser, R. Lindahl \& H. Weiner, (Ed), pp. 104-109, Purdue University Press, ISBN 978-155753-384-5, West Lafayette, IN.

Valenzuela-Soto, E.M., Velasco-García R., Mújica-Jiménez C., Gaviria-González L., \& Muñoz-Clares R.A. (2003). Monovalent cations requirements for the stability of 
betaine aldehyde dehydrogenase from Pseudomonas aeruginosa, porcine kidney and amaranth leaves. Chemico-Biological Interactions, Vol.143-144, No.3, (February 2003), 139-148, ISSN 0009-2797.

Valenzuela-Soto, E.M., \& Muñoz-Clares, R.A. (1994). Purification and properties of betaine aldehyde dehydrogenase extracted from detached leaves of Amaranthus hypocondriacus L. Subjected to water deficit. Journal of Plant Physiology, Vo.143, No.17, (November 1993), 145-152, ISSN 0176-1617.

Valenzuela-Soto, E.M., \& Muñoz-Clares, R.A. (1993) Betaine-aldehyde dehydrogenase from leaves of Amaranthus hypocondriaus L. Exhibits an iso ordered $\mathrm{Bi}$ Bi steady state mechanism. Journal of Biological Chemistry, Vol.268, No.32, (November 1993), 2381823824, ISSN 0021-9258.

Vasiliou, V., Bairoch, A., Tipton, K.F., \& Nebert, D.W. (1999). Eukaryotic aldehyde dehydrogenase (ALDH) genes: human polymorphisms, and recommended nomenclature based on divergent evolution and chromosomal mapping. Pharmacogenetics, Vol.9, No.4, (August 1999), 421-434, ISSN 0960-314.

Vallari, R.C., Pietruszko, R. (1982). Human aldehyde dehydrogenase: mechanism of inhibition of disulfiram. Science, Vol. 216, No.4546, (May 7 1982), 637-639 ISSN 0036-8075.

Vaz, F.M., Fouchier, S.W., Ofman R., Sommer M., Wanders R.J.A. (2000). Molecular and biochemical characterization of rat $\gamma$-trimethylaminobutyraldehyde dehydrogenase and evidence for the involvement of human aldehyde dehydrogenase 9 in carnitine biosíntesis. Journal of Biological Chemistry, Vol.275, No.10, (March 2000), 7390-7394, ISSN 0021-9258.

Vaziri, N.D. (2004). Roles of oxidative stress and antioxidant therapy in chronic kidney disease and hypertension. Current Opinion in Nephrology and Hypertension, Vol.13, No.1, (January 2004) 93-99, ISSN 1062-4821.

Velasco-García, R., Chacón-Aguilar, V.M., Hervert-Hernández, D., \& Muñoz-Clares R.A. (2003). Inactivation of betaine aldehyde dehydrogenase from Pseudomonas aeruginosa and Amaranthus hypochondriacus L. leaves by disulfiram. ChemicoBiological Interactions, Vol.143-144, No.3, (February 2003), 149-158 ISSN 0009-2797.

Velasco-García, R., Mújica-Jiménez, C., Mendoza-Hernández, G., \& Muñóz-Clares, R.A. (1999). Rapid purification and properties of betaine aldehyde dehydrogenase from Pseudomonas aeruginosa. Journal of Bacteriology, Vol.181, No.4, (February 1999), 12921300, ISSN 0021-9193.

Weretilnyk, E.A., \& Hanson, A.D. (1989). Betaine aldehyde dehydrogenase from spinch leaves: purification, in vitro translation of the mRNA, and regulation by salinity. Archives of Biochemistry and Biophysics, Vol.271, No.1, (May 1989), 56-63, ISSN 003-9861.

Zhang, L., Xiao, N., Pan, Y. Zheng, Y., Pan, Z., Luo, Z., Xu, X., \& Liu Z. (2010) Binding and Inhibition of Copper Ions to RecA Inteins from Mycobacterium tuberculosis. Chemistry A European Journal, Vol.16, No.14, (April 2010), 4297-4306, ISSN 521-3765.

Zou, A., Li, N., \& Cowley, A. (2001). Production and actions of superoxide in the renal medulla. Hypertension, Vol.37, No.2, (February 2001), 547-553, ISSN 0194-911. 


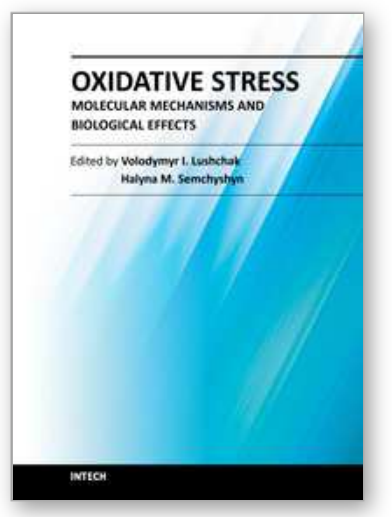

\section{Oxidative Stress - Molecular Mechanisms and Biological Effects}

Edited by Dr. Volodymyr Lushchak

ISBN 978-953-51-0554-1

Hard cover, 362 pages

Publisher InTech

Published online 25, April, 2012

Published in print edition April, 2012

Since the discovery of free radicals in biological systems researchers have been highly interested in their interaction with biological molecules. Denoted in 1980, and due to fruitful results and ideas, oxidative stress is now appreciated by both basic and applied scientists as an enhanced steady state level of reactive oxygen species with wide range of biological effects. This book covers a wide range of aspects and issues related to the field of oxidative stress. The association between generation and elimination of reactive species and effects of oxidative stress are also addressed, as well as summaries of recent works on the signaling role of reactive species in eukaryotic organisms. The readers will gain an overview of our current understanding of homeostasis of reactive species and cellular processes they are involved in, as well as useful resources for further reading.

\section{How to reference}

In order to correctly reference this scholarly work, feel free to copy and paste the following:

Jesús A. Rosas-Rodríguez, Hilda F. Flores-Mendoza, Ciria G. Figueroa-Soto, Edgar F. Morán-Palacio and Elisa M. Valenzuela-Soto (2012). Structural and Activity Changes in Renal Betaine Aldehyde Dehydrogenase Caused by Oxidants, Oxidative Stress - Molecular Mechanisms and Biological Effects, Dr. Volodymyr Lushchak (Ed.), ISBN: 978-953-51-0554-1, InTech, Available from: http://www.intechopen.com/books/oxidative-stressmolecular-mechanisms-and-biological-effects/impact-of-oxidants-on-the-activity-structure-and-conformationalstability-of-renal-betaine-aldehyde

\section{INTECH}

open science | open minds

\section{InTech Europe}

University Campus STeP Ri

Slavka Krautzeka 83/A

51000 Rijeka, Croatia

Phone: +385 (51) 770447

Fax: +385 (51) 686166

www.intechopen.com

\section{InTech China}

Unit 405, Office Block, Hotel Equatorial Shanghai

No.65, Yan An Road (West), Shanghai, 200040, China

中国上海市延安西路65号上海国际贵都大饭店办公楼405单元

Phone: +86-21-62489820

Fax: $+86-21-62489821$ 
(C) 2012 The Author(s). Licensee IntechOpen. This is an open access article distributed under the terms of the Creative Commons Attribution 3.0 License, which permits unrestricted use, distribution, and reproduction in any medium, provided the original work is properly cited. 